\title{
First report of predation on floral visitors by crab spiders on Croton selowii Baill. (Euphorbiaceae)
}

\author{
Reinaldo Rodrigo Novo ${ }^{1}$, Jefferson Thiago Souza ${ }^{1}$ e Cibele Cardoso de Castro ${ }^{1,2}$
}

Recebido em 24/03/2009. Aceito em 16/11/2009

\begin{abstract}
RESUMO - (Primeiro registro de predação de visitantes florais por aranhas-caranguejo em Croton selowii Baill. (Euphorbiaceae)). Na literatura tem sido amplamente registrado que aranhas Thomisidae predam visitantes florais de várias espécies de planta. Neste estudo nós apresentamos observações de Croton selowii Baill. (Euphorbiaceae), uma espécie monóica, abrigando aranhas Thomisidae em uma área de restinga de Pernambuco, Brasil. A espécie é visitada por invertebrados de várias ordens e vários deles são predados pelas aranhas, principalmente espécies de Diptera. As aranhas apresentaram um comportamento de esfregar as pernas dianteiras dentro das flores, o que pode ser interpretado como uma estratégia de camuflagem das pernas. Croton selowii parece representar um bom sítio de forrageamento para essas aranhas, pois possui um sistema de polinização generalista, sendo visitado por ampla gama de invertebrados e floresce em um período de baixa disponibilidade de flores na área.
\end{abstract}

Palavras-chave: polinização, predação, restinga

ABSTRACT - (First report of predation on floral visitors by crab spiders on Croton selowii Baill. (Euphorbiaceae)). In the literature it has been extensively mentioned that crab spiders (Araneae: Thomisidae) prey on floral visitors of several plant species. Here we present observations of Croton selowii Baill. (Euphorbiaceae), a monoecious species harboring individuals of crab spiders in an area of coastal vegetation of Pernambuco state, Brazil. The species is visited by several invertebrate orders, and some of them were preyed upon by the spiders, mainly Diptera species. The spiders rubbed the forelimbs within the flowers, which may constitute a strategy to camouflage these structures. Croton selowii seems to represent a suitable foraging site for the spiders, because it has a generalist pollination system (thus being visited by a wide range of invertebrate species) and blooms in a period of low flower resource availability in the area.

Key words: pollination, predation, coastal vegetation

\section{Introduction}

The crab spiders (Araneae: Thomisidae) prey on floral visitors and present the sit-and-wait strategy: they remain camouflaged in the inflorescences waiting for invertebrates (Dukas \& Morse 2003; Robertson \& Maguire 2005). There is evidence that the presence of crab-spiders can reduce flower visitation rates (Suttle 2003; Reader et al. 2006), and diminish pollinator density, causing a negative impact on plant reproductive success (Dukas \& Morse 2003; Gonçalves-Souza et al. 2008). However, other studies discuss the beneficial effects of these flower-dwelling spiders on their host plant, such as predation on phytophagous herbivores, which can has a positive influence on seed production (Romero \& Vasconcellos-Neto 2004).

Plant species of some angiosperm families were recorded as being occupied by crab spiders, such as Asteraceae (Romero \& Vasconcellos-Neto 2003), Asclepiadaceae (Kareiva et al. 1989), Fabaceae (Chien \& Morse 1998) and Rosaceae (Romero \& VasconcellosNeto 2004), but to date, there are no records of this interaction in Croton L. (Euphorbiaceae) species. This short communication aims to describe general aspects of the interaction between crab spiders, C. selowii flowers and their floral visitors in an area of coastal vegetation of Pernambuco, Brazil.

\section{Material and methods}

Croton sellowii Baill. is a monoecious shrub species with restricted distribution in coastal formations of Brazil (J. S. Silva, pers. comm.). In the Reserva Particular do Patrimônio Natural "Nossa Senhora do Outeiro de Maracaípe", Ipojuca, Pernambuco, Brazil (08³1'48”S; 35001'48”W), it occurs mainly on forest edges and gaps. Naturalistic observations were done in September 2008. To observe spiders' behavior, twenty flowering individuals of $C$. selowii were observed between 9:00 and 11:00 h, and between 14:00 and 16:00 h (total of $80 \mathrm{~h}$ ). Floral visitors were collected and identified to the family level. Floral scent was recorded and the presence of regions of odor emission was tested in 20 flowers from different individuals and populations, using the neutral red technique (Dafni 1992). Forty-five individuals from different populations were checked for the presence of spiders, which were collected and identified by specialists.

\section{Results and discussion}

Flowers were visited by 21 morpho-species of several invertebrate orders, such as Hymenoptera (five Sphecidae, three Vespidae, one Pompilidae, two Apidae, one Megachilidae, one Adrenidae and one Formicidae morph species), Lepidoptera (two Hesperiidae), Diptera (two Bombiliidae, one Muscidae and one Syrphidae) and Heteroptera (one Coreidae). A total of 31 individuals (69\%) harbored individuals of Misumenoides cf. paucispinosus, Misumenops pallens (Keyserling 1880) and/or Misumenops sp. (Araneae: Thomisidae), which prey on floral visitors, mainly on flies. It was also observed predation on bees and the phytophagous species of Coreidae. All visitors that were preyed upon touched the anthers or the stigma, being considered as potential pollinators.

\footnotetext{
1 Universidade Federal Rural de Pernambuco, Departamento de Biologia, Área de Botânica, Programa de Pós-graduação em Botânica, Recife, PE, Brasil

2 Autor para correspondência: cibelecastro@hotmail.com
} 

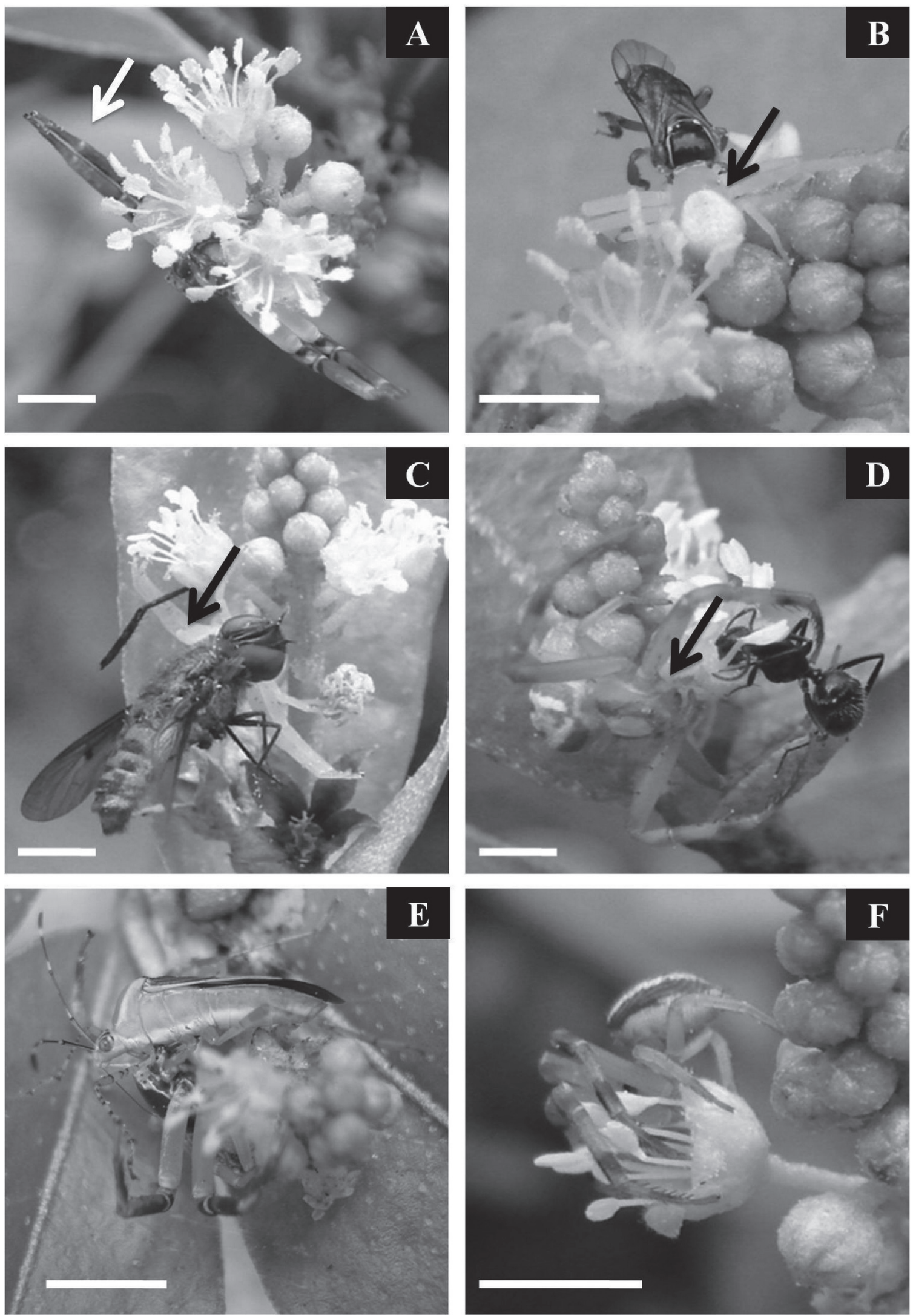

Figure 1. Crab spiders (Thomisidae-Araneae; arrows) on flowers of Croton selowii Baill. (Euphorbiaceae) in an area of coastal vegetation in Ipojuca, PE, Brazil. (A) Misumenoides cf. paucispinosus camouflaged on an inflorescence. (B-C) Misumenops pallens (Keyserling 1880) preying on a bee and a Syrphidae species, respectively. (D) predation attempt of Misumenops sp. on Camponotus sp.. (E) M. cf. paucispinosus preying on a Coreidae species. (F) Misumenops sp. collecting floral substances. Bars $=0,3 \mathrm{~cm}$. 
In most observations the spiders positioned the forelimbs perpendicularly outstretched to their bodies' axis (Fig. 1A). They resemble inflorescence structures, being easily confused with buds and flowers (Fig. 1). Furthermore, it was observed that some individuals introduce a forelimb within the flower and rub on the opposite forelimb (Fig. 1F). When a visitor approaches the inflorescence, the spider attacks and consumes it immediately (Fig. 1B-E). Most floral visitors apparently did not perceive the spider's presence, but a bee species (Apidae) gave up the visit when it detected the spider, similarly to what was recorded by other studies (e.g., Dukas \& Morse 2003; Robertson \& Maguire 2005).

Studies show that these Thomisidae spiders (including species of Misumenoides F.O.P-Cambridge 1900 and Misumenops F.O.P-Cambridge 1900) can modify, gradually and reversibly, their body color to resemble the flowers, a behavior that avoids their recognition by floral visitors (Schmalhofer 2000), and even may enhance flower attraction (Heiling et al. 2005). Some studies suggest that the forelimbs seem to be the spider trait recognized by pollinators (mainly hymenopterans), thus both the spider position in the plant and the apparent use of floral substances observed here seem to constitute strategies to camouflage the forelimbs (Gonçalves-Souza et al. 2008). Croton selowii flowers present a citric fragrance and regions of odor emission distributed on sexual elements.

Croton selowii seems to represent a suitable foraging site for the spiders in the study area. It has a generalist pollination system (thus being visited by a wide range of invertebrate species) and blooms in a period of low flower resource availability in the area (Medeiros et al. 2006). Consequently, it presents high visitation rates, mainly in the morning (pers. obs.). This short communication is, to our best knowledge, the first report of crab spiders preying on pollinators of $C$. selowii.

\section{Acknowledgements}

The authors thank Dr. Arno Antonio Lise (Museu de Ciências e Tecnologia, Pontifícia Universidade Católica do Rio Grande do Sul) for the identification of the spiders, the Plebeia Laboratory and Inara Roberta Leal (Universidade Federal de Pernambuco) for the identification of the flies and the ant, respectively, Luci Duarte da Rosa Borges Regis (Universidade Federal Rural de Pernambuco) for the identification of the other invertebrates and the Conselho Nacional de Desenvolvimento Científico e Tecnológico (CNPq, Brazil) for the grants awarded to R. R. Novo and J. T. Souza. This study is part of the project "Sexual systems, breeding systems and pollination syndromes of a coastal formation in a conservation unity of Pernambuco state", coordinated by C.C. Castro and funded by Fundação de Amparo à Pesquisa do Estado de Pernambuco (FACEPE).

\section{References}

Chien, S. A. \& Morse, D. H. 1998. The roles of prey and flower quality in the choice of hunting sites by adult male crab spiders Misumena vatia (Araneae: Thomisidae) Journal of Arachnology 26: 238-243.

Dafni, A. 1992. Pollination ecology: a practical approach. New York, Oxford University Press.

Dukas, R. \& Morse, D. H. 2003. Crab spiders affect flower visitation by bees. Oikos 101: 157-163.

Gonçalves-Souza, T.; Omena, P. M.; Souza, J. C. \& Romero, J. C. S. 2008. Trait-mediated effects on flowers: artificial spiders deceive pollinators and decrease plant fitness. Ecology 89: 2407-2413.

Heiling A. M.; Chittka, L.; Cheng, K. \& Herberstein, M. E. 2005. Colouration in crab spiders: substrate choice and prey attraction. The Journal of Experimental Biology 208: 1785-1792.

Kareiva, P.; Morse, D. H. \& Eccleston, J. 1989. Stochastic prey arrivals and crab spider giving-up times: simulations of spider performance using the simple "rules of thumb". Oecologia 78: 542-549.

Medeiros, D. P. W.; Lopes, A. V. \& Zickel, C. S. 2006. Phenology of woody species in tropical coastal vegetation, northeastern Brazil. Flora 202: 513-520.

Reader, T; Higginson, A. D.; Barnard, C. J \& Gilbert, F. S. 2006. The effects of predation risk from crab spiders on bee foraging behavior. Behavioral Ecology 17:933-939.

Robertson, I. C. \& Maguire, D. K. 2005. Crab spiders deter insect visitations to slickspot peppergrass flowers. Oikos 109: 577-582.

Romero, G. Q. \& Vasconcellos-Neto, J. 2003. Natural history of Misumenops argenteus Rinaldi (1988) (Araneae: Thomisidae): seasonality and diet on Trichogoniopsis adenantha (Asteraceae). Journal of Arachnology 31: 297-304.

Romero, G. Q. \& Vasconcellos-Neto, J. 2004. Beneficial effects of flowerdwelling predators on their host plant. Ecology 85: 446-457.

Schmalhofer, V. R. 2000. Diet-induced and morphological color changes in juvenile crab spiders (Araneae: Thomisidae). Journal of Arachnology 28: 56-60.

Suttle, K. B. 2003. Pollinators as mediators of top-down effects on plants. Ecology Letters 6: 688-694. 